\title{
Pesticide Resistance in Stored-Product Insects and Alternative Biorational Management: A Brief Review
}

\author{
Farid Talukder* \\ Department of Crop Sciences, College of Agricultural and Marine Sciences \\ Sultan Qaboos University, P.O. Box 34, Al-Khod 123, Sultanate of Oman \\ المناعة ضد المبيدات في حشرات المخازن والطريقة الحيوية \\ البديلة المقبولة في إدارتها: إسـتعـراض هوجـز \\ فريد أحمد تالوكدار \\ الخلاصة: تستخدم المبيدات الثائعة (التقليدية) كجزء أساسي في عمليات مكافحة آفات مخازن الحبوب والأغذية. الكثير من هذه المبيدات الثائعة المستخدمة شكلت مشاكل عديد

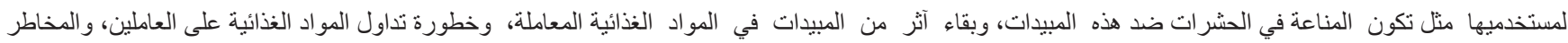

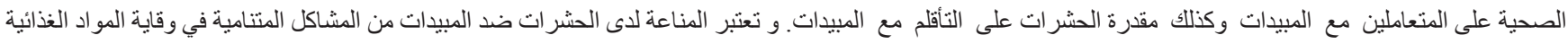

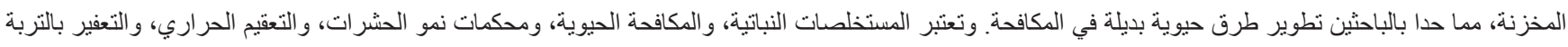

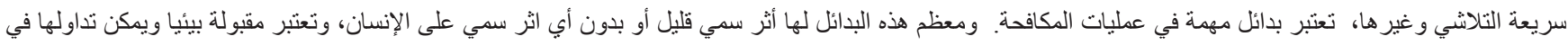 \\ المنتجات الغذائية المخزنة. \\ كلمات مفتاحية :المواد المخزنة، الحشرات ، الآفات، المبيدات الحشرية ، المناعة، الأثر المتبقي للمبيدات، إدارة الآفات الزراعية التقليدية، إدارة الآفات الزراعية البديلة
}

ABSTRACT: Conventional pesticides are being used as the major tools for stored grain and food protection. Many conventional pesticides have created problems including pesticide resistance, toxic residues in the treated products, handling hazards, health hazards to operatives and pest resurgence. Among these, the incidence of pesticide resistance is a growing problem in stored product protection. Problems associated with synthetic pesticides, especially pesticide resistance, have created a worldwide interest in the development of alternative biorational strategies. Plant-derived materials, biological control agents, insect growth regulators, solar disinfestation systems, use of inert dusts and diatomaceous earth, etc., are potential viable alternatives. Most of these alternatives have low toxicity or are not toxic to humans, making them environmentally acceptable and enabling them to be incorporated in stored product protection.

Keywords: Stored-products, insect pests, insecticides, insecticide resistance, insecticide residues, conventional insect pest management, alternative insect pest management.

\section{Introduction}

It is generally accepted that settled agriculture began about 10,000 years ago and the practice of storing food grains started about 4,500 years ago as a safeguard against poor harvests and famines (Saxena et al., 1988). Since then, insect-pests appeared as one of the major constraints to agricultural production before harvest and during storage of crops. Archaeological evidence showed that many currently available stored-products insect species (not all of them pests) of the families Anobiidae, Bostrichidae, Braconidae, Cleridae, Curculionidae, Dermestidae, Ptinidae, Pyralidae, Silvanidae and Tenebrionidae were found in ancient Egyptian tombs (Levinson and Levinson, 1985). It is therefore evident that conservation of reserve food stocks and stored crops is necessary to ensure a continuous supply at stable prices

More than 20,000 species of pre- and post-harvest pests destroy approximately one-third of the world's food production, valued annually at more than $\$ 100$ billion, among which the highest losses ( $43 \%$ of potential production) occur in developing Asian and African countries. Rice and maize crops, the staple foods in many developing countries, are among those most affected (Jacobson, 1982; Ahmed and Grainge, 1986). In the USA and Canada, $20-26 \%$ of stored wheat was infested by stored-product pests (White et al., 1985). Insects are the most damaging stored pests and the most difficult to control due to their small size, feeding behaviour and ability to attack grain before harvest. In India, losses caused by insects accounted for $6.5 \%$ of stored grains (Raju, 1984). In Ethiopia, the proportion of damaged grains due to insect pests was $29.3 \%$ at farmers' storages (Tadesse and Basedow, 2004). In tropical countries, grain harvested at high ambient temperatures and delivered into storage loses heat slowly and hence provides ideal conditions for a rapid build-up of many grain insects (Wallbank and Greening, 1976). Insect infestation of stored grain causes weight and quality losses that lead to a reduction of commercial value and seed germination. 
Among the insect species causing infestations and serious damage to stored commodities, Tribolium castaneum (Herbst), T. confusum Duval, Rhyzopertha dominica (Fabricius), Sitophilus granarius L., S. zeamais Motschulsky, Callosobruchus chinensis L., C. maculatus (Fabricius), Oryzaephilus surinamensis (L.), Acanthoscelides obtectus (Say), Prostephanus truncatus (Horn), Lasioderma serricorne (Fabricius), Ephestia elutella (Hubner) are major pests (Irshad and Jilani, 1990; Zettler and Cuperus, 1990; Sayaboc et al., 1992; Talukder and Howse, 1994; Talukder and Howse, 1995; Yao and Lo, 1995; Benhalima et al., 2004). Prostephanus truncatus and S. zeamais have been reported as the two most serious pests of stored maize in sub-Saharan Africa and smallholder farmers are in urgent need of guidelines for their proper management (Holst et al., 2000). Callosobruchus spp. are major stored product insect-pests of legume crops in the tropics and sub-tropics and cause considerable economic losses (Chauhan and Ghaffar, 2002).

The losses of stored grains due to insect infestation is a serious problem, particularly in villages and towns in developing countries. Tropical climatic conditions, poor sanitation and use of inappropriate storage facilities all encourage insect pest attack and are often highly favourable for insect growth and development (Jacobson, 1982; Talukder, 1995). Burkholder (1977) has suggested that more effective control of storage pests in agricultural and domestic premises would immediately increase the amount of edible grain and food without any increase in agricultural productivity.

The efficient control and prevention of insect pests of stored food commodities has long been the goal of entomologists throughout the world (Talukder, 1995). Although many methods of control are now being used, the agriculture industry is seeking safer and more economical means. In recent years, inert gases, radiation, pathogens, growth regulators and pheromones have all been used for stored-product insect control. All these can be combined with the older methods of control (resulting in integrated pest control), namely: sanitation, inspection, good packaging, good storage facilities and pesticides, etc. to provide integrated pest management (Burkholder, 1977).

Synthetic pesticides are the major tools for stored grain protection in developed countries. They are valued for their uniform and rapid effectiveness, ease of shipment, storage, application and often relatively long-term persistence. They can be classified, according to type of formulation, into fumigants, liquid, powder etc. However, considerable problems may arise from the continued application of these insecticides, including genetic resistance of insect species, toxic residues in the treated products, handling hazards, health hazards to operatives and pest resurgence (Schoonhoven, 1982; Sharaby, 1988; Chiu, 1989; Rembold, 1989). Continuous and heavy usage of synthetic insecticides results in direct toxicity to nontarget organisms such as beneficial parasitoids, predators, etc. In addition, certain chemicals may get concentrated in food chains and may cause lethal effects on the food consumers. These problems lead to rapidly rising application and marketing costs with reduced benefits. In this review, I shall focus on pesticide resistance as one of the major problems with conventional pesticides used in stored-product insect pest management and the use of alternative biorational methods as a possible solution to pesticide resistance.

\section{The Pesticide Resistance Problem}

The incidence of pesticide resistance is a growing problem in stored-product protection. Resistance to one or more pesticides has been reported in at least 500 species of insects and mites (Georghiou, 1990). An insecticide resistance problem in different stored-product insects has been reported from many countries including Australia, Bahrain, Canada, Central African Republic, China, Cyprus, Egypt, Ethiopia, Gambia, Germany, Greece, Guyana, India, Japan, Kenya, Malawi, Malaysia, Morocco, Nepal, Nigeria, Pakistan, Philippines, Senegal, Somalia, South Africa, Syria, Taiwan, Uganda, United Kingdom, USA, Zambia (Dyte and Halliday, 1985; Prickett, 1987; Rassman, 1988; Irshad and Jilani, 1990; Zettler and Cuperus, 1990; Sayaboc et al., 1992; Yao and Lo, 1995; DARP, 2003; Benhalima et al., 2004). Storedproduct insect pests were found to be resistant against several insecticides including bioresmethrin, carbaryl, chlorpyrifo, chlorpyrifos-methyl, cyanophos, cyfluthrin, cyhalothrin, cypermethrin, DDT, deltamethrin, diazinon, dichlorvos, ethylene dibromide, fenitrothion, lindane, malathion, methyl bromide, permethrin, phosphine, phoxim, pirimiphos-methyl, promecarb, propoxur, pyrethrins, temephos, tetrachlorvinphos (DARP, 2003). The aforementioned publications documented the extent of the resistance to different groups of conventional insecticides in stored-product insect pests around the world This frustrating situation indicates the powerlessness of conventional pest management strategies against insect pests of stored products.

Most of the important pests of stored products have shown resistance to more than one kind of pesticide. The resistance of certain stored products pests to two of the more widely used food industry pesticides has reached the highest levels ever recorded in the USA (Fehrenbach, 1991). The development of cross-resistance (to different members of the same pesticide group) and multi-resistance (to different pesticide groups) in insect strains of many important insect species is a serious concern all over the world (Dyte and Halliday, 1985; Zettler and Cuperus, 1990; Chaudhry, 1997). The rapid spread of resistant insect strains through international trade is indicative of a problem likely to occur with stored products pests. White and Watters (1984) reported that malathion-resistant stored grain insects enter Canada primarily through international trade. Table 1 shows the extent of insecticide resistance of some major stored-product insect pests.

Organophosphates and fumigants are two major classes of pesticides used in management of insect pests of stored-products. I will use malathion (an 
Table 1. Insecticide resistance status of major stored-product insect pests (APRD, 2007).

\begin{tabular}{|c|c|c|}
\hline Common Name & Species & $\begin{array}{l}\text { Number of } \\
\text { Insecticides } \\
\text { Resistant to }\end{array}$ \\
\hline Red flour beetle & Tribolium castaneum (Herbst.) & 34 \\
\hline $\begin{array}{l}\text { Saw-toothed } \\
\text { grain beetle }\end{array}$ & Oryzaephilus surinamensis (L.) & 11 \\
\hline Granary weevil & Sitophilus granarius (L.) & 10 \\
\hline Rice weevil & Sitophilus oryzae (L.) & 08 \\
\hline Maize weevil & Sitophilus zeamais Motschulsky & 09 \\
\hline $\begin{array}{l}\text { Lesser grain } \\
\text { borer }\end{array}$ & Rhyzopertha dominica (Fab.) & 08 \\
\hline $\begin{array}{l}\text { Confused flour } \\
\text { beetle }\end{array}$ & Tribolium confusum (Duval) & 05 \\
\hline Cowpea weevil & $\begin{array}{l}\text { Callosobruchus maculates } \\
\text { (Fab.) }\end{array}$ & 02 \\
\hline $\begin{array}{l}\text { Rusty grain } \\
\text { beetle }\end{array}$ & $\begin{array}{l}\text { Cryptolestes ferrugineus } \\
\text { (Stephens) }\end{array}$ & 01 \\
\hline Cigarette beetle & Lasioderma serricorne (Fab.) & 01 \\
\hline
\end{tabular}

organophosphate) and phosphine (a fumigant), both important pesticides commonly used for the protection of stored-products, to illustrate the problem of resistance to these two major classes of pesticides.

\section{Resistance to Malathion}

Currently, there are 122 insect pest species which are resistant to Malathion (DARP, 2003). Malathion resistance in stored-product insect-pests has been reported from all over the world (Rassmann, 1988; Sayaboc and Acda, 1990; Zettler and Cuperus, 1990). Navarro et al. (1986) reported malathion resistance of $T$. castaneum, $O$. surinamensis, $S$. oryzae and $R$. dominica. Malathion resistance in $T$. castaneum was reported from India by Pasalu and Bhatia (1983). In Germany, malathion resistance was detected in S. granarius and S. oryzae (Rassmann, 1988). Reports showed that adult T. castaneum, in Pakistan has developed a 56-fold increase in resistance against malathion, and in the Philippines, red flour beetles exhibited a 57-fold increase in resistance to malathion (Saleem and Shakoori, 1989; Gibe and Motoyama, 2002). Malathion resistant strains of this pest species were reported from different Asian countries (Irshad and Jilani, 1990; Dhaliwal and Chawla, 1997; Gibe and Motoyama, 2002). Irshad and Jilani (1990) found that forty strains of $T$. castaneum, collected from various locations of Pakistan, all were resistant against malathion. In the Philippines, Sayaboc and Acda (1990) collected 61 populations of $T$. castaneum and $R$. dominica, all of which were found to be resistant to malathion. Approximately one-third of $O$. surinamensis strains tested in U.K. during the 1984-85 harvest showed resistance to malathion (Prickett, 1987). Zettler and Cuperus (1990) reported that from Oklahama, USA, all collected strains of $T$. castaneum and $R$. dominica were resistant to malathion. In another study, Zettler (1991) reported that throughout the United States, $82 \%$ of the 17 strains of T. confusum, and $93 \%$ of the 28 strains of $T$. castaneum were resistant to malathion. Malathion-specific resistance is widespread and stable in natural populations even in the absence of pesticide exposure (Arnaud and Haubruge 2002).

\section{Resistance to Phosphine}

Fumigation is still one of the most effective methods for the prevention of stored product losses from insect pests, but stored-product insects have been showing a slow upsurge in fumigation resistance (Donahaye, 2000). Lately, the availability of fumigants for insect control has dwindled drastically. Only two fumigants are still in use, namely methyl bromide and phosphine. The former is suspected of leaving residues that are harmful to warmblooded animals (Dansi et al., 1984). There are alarming indications of widespread resistance to phosphine in several species of stored product insects in many countries, which in some instances may have caused control failures (Chaudhry, 1997). Benhalima et al. (2004) investigated the phosphine resistance status of insect pests in Morocco and found that, with the exception of one population of $S$. oryzae, all samples tested contained phosphine-resistant individuals. Attia and Greening (1981) reported on phosphine resistance on $R$. dominica, T. castaneum and $T$. confusum in Australia. The levels of phosphine resistance in C. ferrugineus, O. surinamensis, $R$. dominica and $T$. castaneum from Bangladesh are certainly higher than any previously known in any natural infestation (Dyte and Halliday, 1985). Zettler and Cuperus (1990) found a strain of T. castaneum resistant to phosphine in Oklahoma, USA. Zettler and Keever (1994) reported phosphine resistance in L. serricorne in the USA.

Fumigation is still one of the most effective methods for the prevention of stored-product losses from insect pests. Lately, the availability of fumigants for insect control has dwindled drastically. Only two fumigants are still in use, namely methyl bromide and phosphine. However, methyl bromide is suspected of leaving residues that are harmful to warm-blooded animals (Dansi et al., 1984). Recently a slow increase in fumigation resistance have been observed in stored-product insects (Donahaye, 2000). Alarming indications of widespread resistance to phosphine have emerged in several species of storedproduct insects in many countries, which in some instances may have caused control failures (Chaudhry, 1997). Benhalima et al. (2004) investigated the phosphine resistance status of insect pests in Morocco and found that, with the exception of one population of $S$. oryzae, all samples tested contained phosphine-resistant individuals. Attia and Greening (1981) reported phosphine resistance in $R$. dominica, T. castaneum and T. confusum in Australia. The levels of phosphine resistance in C. ferrugineus, $O$. surinamensis, R. dominica and T. castaneum from 
Bangladesh are certainly higher than any previously known in any natural infestation (Dyte and Halliday, 1985). Zettler and Cuperus (1990) have found a strain of T. castaneum resistant to phosphine in Oklahoma, USA. Zettler and Keever (1994) reported phosphine resistance in L. serricorne in the USA.

\section{Alternative Pest Control Methods}

There is an increasing dichotomy between the demands of the first world for quality food uncontaminated by insecticidal residues, and the desperate need of thirdworld populations to maintain and protect their harvested grain from the deprivations of insects, so as to maintain a minimum level of food security.

The increasingly serious problems of resistance to pesticides and of contamination of the biosphere associated with the large-scale use of broad-spectrum synthetic pesticides have directed the need for development of alternative strategies, such as: 1 ) biorational chemicals which have minimal potential for development of resistance but are effective, pest specific, safe and economical; 2) biological control agents; and 3) physical and ecological methods (Heyde et al., 1984; Talukder and Howse, 1995; Hermawan et al., 1997; Talukder and Miyata, 2002).

\section{Biorational chemicals}

Researchers are currently seeking new classes of naturally occurring pesticides that might be compatible with newer pest control approaches. Plant-derived materials have been found to be highly effective, more readily biodegradable, less likely to contaminate the environment and to have lower potential to produce resistance, making them viable alternatives to synthetic pesticides (Talukder and Howse, 1995; Shaaya et al., 1997; Talukder and Miyata, 2002; Park et al., 2003; Khan and Gumbs, 2003). Talukder et al. (2004) recently reported that potential use of bioactive plant materials in storage pest management systems because they are economical and environmentally friendly.

These chemicals could have lethal effects on storedproduct pests or could affect their development and reproduction. Insect growth regulators (IGRs), a class of biorational compounds that disrupt the normal development of insects, can be used as an alternative in stored product insect-pest protection (Mondal and Parween, 2000). IGRs affect the biology (embryonic and post-embryonic development, reproduction, feeding, and behavior) of treated insects. Unlike conventional insecticides, IGRs do not exhibit quick knockdown or cause mortality, but long-term exposure to these compounds stops population growth of pests. IGRs could have natural or synthesized active ingredients. Many of the plant-derived bioactive chemicals have insect growth regulator properties.

The screening for insecticidal principles from several medicinal herbs showed that the root bark of Dictamnus dasycarpus Turcz. possessed significant feeding deterrence against two stored-product insects (Liu et. al., 2002). Owusu (2001) suggested natural and cheaper methods for the control of stored-product pests of cereals, with traditionally useful Ghanaian plant materials. Plant extracts showed deleterious effects on the growth and development of insects and reduced larval, pupal, and adult weight significantly, lengthened the larval and pupal periods and reduced pupal recovery and adult eclosion (Khanam et al., 1990).

Plant oils can play an important role in stored product protection and reduce the need for, and risks associated with, the use of conventional insecticides. The fumigant toxicity of a large number of essential oils extracted from various spices and herb plants was assessed against several major stored product insects (Shaaya et al., 1997). Singal and Chauhan (1997) showed that pigeon pea seed treated with neem seed kernel powder or neem seed oil prevented egg laying of $C$. chinensis for up to 8 months. Two major constituents of the essential oil of garlic (Allium sativum L.), methyl allyl disulfide and diallyl trisulfide, were found to be potent contact toxicants, fumigants and feeding deterrents against $S$. zeamais and T. castaneum (Huang et al., 2000). Xie et al. (1995) reported the repellency and toxicity effects of azadirachtin and neem extracts on $C$. ferrugineus, $S$. oryzae and T. castaneum. Obeng-Ofori and Reichmuth (1997) reported the high toxicity and protectant potential of eugenol against $S$. granarius, $S$. zeamais, T. castaneum and P. truncatus. The essential oil of Artemisia annua L. was found to be toxic and repellent against $T$. castaneum and C. maculatus (Tripathi et al., 2000). The essential oil vapours distilled from anise, cumin, eucalyptus, oregano and rosemary were reported to have fumigant properties, causing $100 \%$ mortality of the eggs of T. confusum, and Ephestia kuehniella Zeller (Tunc et al., 2000).

\section{Biological control}

Biological control agents, such as bacteria, fungi, virus, parasitoids, predators etc. appear to be environmentally sound and potentially viable alternatives to chemical control for stored-product insect pest management. So far, only Bacillus thuringiensis Berliner (Bt) among microbial pesticides has been approved for application against stored product insect pests (Abdel-Razek, 2002). The use of predators and parasitoids as biological control agents is also another alternative. Trichogramma species were assessed for their suitability as bio-control agents against E. cautella (Walker) and E. kuehniella, which are important pests in food manufacturing and processing facilities in Australia (Steidle et al., 2001).

\section{Physical and ecological methods}

The use of kaolinite-based particle film dusts has a potential for use in stored product insect-pests management programs (Arthur and Puterka. 2002). Inert dusts, particularly those based upon activated silicas, are finding increasing use as storage protectants in the grain industry. These materials have been used traditionally as grain protectants by small-scale farmers in the developing 
world (Golob, 1997). More recently, materials including diatomaceous earths and silica aerogels, have been used increasingly in commercial storage in the developed world, replacing conventional chemicals. Diatomaceous earth acts on insect cuticle by absorbing lipids, and perhaps by cuticular abrasion (Lord, 2001). These materials have been shown to control a variety of common storage insect pests. Most of them are practically non-toxic to humans and fully acceptable for the environment.

As a physical or ecological alternative to conventional pesticides, Chauhan and Ghaffar (2002) reported that farmers in semi-arid tropical and humid tropical regions may consider using solar heating as a safe and relatively inexpensive method for disinfesting seeds of pigeon pea, as the solar heat-treated seeds remained free from bruchid damage even after 41 weeks of storage. Post-harvest tobacco control is partially achieved through sanitation and insect monitoring (Blanc et al., 2002).

\section{Conclusions}

Due to the current reliance on synthetic pesticides for the management of stored-product insect pests, a considerable number of problems are arising, including toxic residues in treated products, handling and health hazards, pest resurgence, and genetic resistance of insect species. The extent of the problem of resistance to pesticides in stored-product insects was discussed with reference to its geographical distribution, pest species affected, and number and types of pesticides these pest species have become resistant to. The serious problem of resistance to pesticides has created a worldwide interest in the development of alternative strategies. Among the viable alternatives, the use of plant-derived materials (such as extracts, plant oils, and powders); biological control agents such as Bt and Trichogramma species; insect growth regulators; inert dusts and diatomaceous earth; and solar heating have been discussed. Most of these alternatives were reported as having minimum toxicity to humans and the environment. To stop the increasing pressure of insecticide resistance in insect pests, and also to reduce the chances of pesticide residues in the treated stored-products, a new or alternative management strategy is necessary. Among the discussed alternatives, use of a single method might not be fruitful to resolve the current pesticide resistance problem. Therefore, a combination of two or more alternative control methods or a combination of conventional chemical insecticides and alternative techniques should be considered as a sustainable longterm strategy.

\section{References}

Abdel-Razek, A.S. 2002.Comparative study on the effect of two Bacillus thuringiensis strains of the same serotype on three coleopteran pests of stored wheat Journal of the Egyptian Society of Parasitology 32:415-424.

Ahmed, S. and M. Grainge.1986. Potential of the Neem Tree (Azadirachta indica) for pest control and rural development. Economic Botany 40:201-209.
APRD. 2007. Arthropod Pesticide Resistance Database. USA. Web: http://www.pesticideresistance.org/

Arnaud, L. and E. Haubruge. 2002. Insecticide resistance enhances male reproductive success in a beetle. Evolution 56:2435-2444.

Arthur, F.H. and G.J. Puterka. 2002. Evaluation of kaolinite-based particle films to control Tribolium species (Coleoptera: Tenebrionidae). Journal of Stored Products Research 38:341-348.

Attia, F.I. and H.G. Greening. 1981. Survey of resistance to phosphine in coleopterous pests of grain and stored products in New South Wales. General and Applied Entomology 13:93-97.

Benhalima, H., M.Q. Chaudhry, K.A. Mills and N.R. Price. 2004. Phosphine resistance in stored-product insects collected from various grain storage facilities in Morocco Journal of Stored Products Research 40: 241-249.

Blanc, M., P. Kaelin and F. Gadani. 2002. Bacillus thuringiensis $(\mathrm{Bt})$ for the control of insect pests in stored tobacco: A review. Beitraege-zur-TabakforschungInternational 20:15-22.

Burkholder, W.E. 1977. Manipulation of insect pests of stored products. In: Chemical control of insect behaviour: Theory \& Application. H.H. Shorey and J.J. McKelvey, Jr. (Editors), 345-351. John Wiley and Sons, New York.

Chaudhry, M.Q. 1997. A review of the mechanism involved in the action of phosphine as an insecticide and phosphine resistance in stored-product insects. Pesticide Science 49:213-228.

Chauhan, Y.S. and M.A. Ghaffar. 2002. Solar heating of seeds: A low cost method to control bruchid (Callosobruchus spp.) attack during storage of pigeonpea Journal of Stored Products Research 38: 87-91.

Chiu, S.F. 1989. Recent advances in research on botanicals in China. In: Insecticides of Plant Origin. J.T. Arnason, B.J.R. Philogene and P. Morand (Editors), 387:69-78. ACS Symposium Series, Washington DC, USA.

Dansi, L., F.L. Vanvelser and C.A.V. Heuden. 1984 Methyl bromide: Carcinogenic effects in the rat fore stomach. Toxicology and Applied Pharmacology 72: 262-271.

DARP. 2003. Database of Arthropods Resistant to Pesticides, Resistant Pest Management at Michigan State University. Web: ttp://www.pesticideresistance. org/DB/

Dhaliwal, B.K. and R.P. Chawla. 1997. Investigation into the specificity of malathion resistance in Tribolium castaneum (Herbst) from Punjab Journal of Insect Sciences 10:42-44.

Donahaye, E.J. 2000. Current status of non-residual control methods against stored product pests. Crop Protection 19:571-576.

Dyte, C.E. and D. Halliday. 1985. Problems of development of resistance to phosphine by insect pests of stored grains. Bulletin, Organization Europeenne et Mediterraneenne pour la Protection des Plantes 15: 51-57.

Fehrenbach, P. 1991. Food pest resistance reaches record levels. Pest Control 59:50. 
Georghiou, G.P. 1990. Overview of insecticide resistance. In: M.B. Green, H.M. Lebaron and W.K. Moberg (Editiors), 19-41. ACS Symposium Series 421. American Chemical Society, Washington, D.C.

Gibe, A.J.G. and N. Motoyama. 2002. Malathion resistance in the red flour beetle, Tribolium castaneum Herbst (Coleoptera:Tenebrionidae). Asia Life Science 11:75-83.

Golob, P. 1997. Current status and future perspectives for inert dusts for control of stored product insects. Journal of Stored Products Research 33:69-79.

Hermawan W., S. Nakajima, R.Tsukuda, K. Fujisaki and F. Nakasuji. 1997. Isolation of an antifeedant compound from Andrographis paniculata (Acanthaceae) against the diamondback moth, Plutella xylostella (Lepidoptera: Yponomeutidae). Applied Entomology and Zoology 32: 551-559.

Heyde, J.V.D., R.C. Saxena and H. Schmutterer. 1984. Neem oil and neem extracts as potential insecticide for control of Hemipterous rice pests. Proceedings of 2 nd International Neem Conference. Rauischholzhausen, 1983. pp. 377-390.

Holst, N., W.G. Meikle and R.H. Markham. 2000. Grain injury models for Prostephanus truncatus (Coleoptera: Bostrichidae) and Sitophilus zeamais (Coleoptera: Curculionidae) in rural maize Stores in West Africa. Journal of Economic Entomology 93:1338-1346.

Huang, Y., S.X. Chen and S.H. Ho. 2000. Bioactivities of methyl allyl disulfide and diallyl trisulfide from essential oil of garlic to two species of stored-product pests, Sitophilus zeamais (Coleoptera: Curculionidae) and Tribolium castaneum (Coleoptera: Tenebrionidae). Journal of Economic Entomology 93:537-543.

Irshad, M. and W.A. Jilani. 1990. Resistance in Tribolium castaneum (Herbst) (Coleoptera: Tenebrionidae) to malathion in Pakistan. Pakistan Journal of Zoology 22:257-262.

Jackobson, M. 1982. Plants, insects, and man - their interrelationship. Economic Botany 36:346-354.

Khan, A. and F.A. Gumbs. 2003. Repellent effect of ackee (Blighia sapida Koenig) component fruit parts against stored-product insect pests. Tropical Agriculture 80: 19-27.

Khanam, L.A.M.; D. Talukder; and A.R. Khan. 1990. Insecticidal property of some indigenous plants against Tribolium confusum Duval (Coleoptera: Tenebrionidae). Bangladesh Journal of Zoology 18:253-256.

Levinson, H.Z. and A.R. Levinson. 1985. Storage and insect species of stored grain and tombs in ancient Egypt. Zeitschrift fuer Angewandte Entomologie 100: 321-339.

Liu, Z.L., Y.J. Xu, J. Wu, S.H. Goh and S.H. Ho. 2002. Feeding deterrents from Dictamnus dasycarpus Turcz against two stored-product insects. Journal of Agricultural and Food Chemistry 50:1447-1450.

Lord, J.C. 2001. Desiccant dusts synergize the effect of Beauveria bassiana (Hyphomycetes: Moniliales) on stored-grain beetles. Journal of Economic Entomology 94:367-372.

Mondal, K.A.M.S.H. and S. Parween. 2000. Insect growth regulators and their potential in the management of stored-product insect pets. Integrated Pest Management Reviews 5:255-295.

Navarro, S., Y. Carmi, Y. Kashanchi and E. Shaaya. 1986. Malathion resistance of stored-product insects in Israel. Phytoparasitica 14:273-280.

Obeng-Ofori, D. and C. Reichmuth. 1997. Bioactivity of eugenol, a major component of essential oil of Ocimum suave (Wild.) against four species of stored-product Coleoptera. International Journal of Pest Management 43:89-94.

Owusu, E.O. 2001. Effect of some Ghanaian plant components on control of two stored-product insect pests of cereals. Journal of Stored Products Research 37:85-91.

Pasalu, I.C. and S.K. Bhatia. 1983. Inheritance of resistance to malathion in Tribolium castaneum (Herbst). Proceedings of Indian Academy of Science (Animal Sciences.), 92:409-414.

Park, C., S.I. Kim and Y.J. Ahn. 2003. Insecticidal activity of asarones identified in Acorus gramineus rhizome against three coleopteran stored-product insects. Journal of Stored Products Research 39:333-342.

Prickett, A.J. 1987. Maintaining insecticide susceptibility in stored grain pests. Proceedings of 4th Working Conference of Stored-Product Protection, Tel Aviv. September 1986. pp 407-417.

Raju, P. 1984. The staggering storage losses- causes and extent. Pesticides 18:35-37.

Rassman, W. 1988. Insecticides resistance in stored products pests. Gesunde Pflanzen 40:39-42.

Rembold, H. 1989. Azadirachtins: Their structure and mode of action. In: Insecticides of Plant Origin. J.T. Arnason, B.J.R. Philogene and P. Morand (Editors), 150-163. CRC Press, Florida.

Saleem, M.A. and A.R. Shakoori. 1989. Toxicity of malathion, permethrin and cypermethrin against resistant and susceptible strains of Tribolium castaneum Herbst. Pakistan Journal of Zoology 21:347-360.

Saxena, R.C., G. Jillani and A.A. Kareem. 1988. Effects of neem on stored grain insects. In: Focus on Phytochemical Pesticides, Volume 1: The Neem Tree. M. Jacobson (Editor), 97-111. CRC Press, Florida.

Sayaboc, P.D. and M.A. Acda. 1990. Resistance of the major coleopterous pests of stored grain to malathion and pirimiphosmethyl. Philippine Entomologist 8: 653-660.

Sayaboc, P.D. O.P. Dixit and V. Harshan. 1992. Resistance of the major coleopterous pests of stored grain to malathion and pirimiphosmethyl. Philippine Entomologist 8:653-660.

Schoonhoven, L.M. 1982. Biological aspects of antifeedants. Entomologia Experimentalis et Applicata 31:57-69. 
Sharaby, A. 1988. Evaluation of some Myrtaceae plant leaves as protectants against the infestation by Sitophilus oryzae L. and Sitophilus granarius L. Insect Science and its Application 9:465-468.

Shaaya, E., M. Kostjukovski, J. Eilberg and C. Sukprakarn. 1997. Plant oils as fumigants and contact insecticides for the control of stored-product insects. Journal of Stored Products Research 33:7-15.

Singal, S.K. and R. Chauhan. 1997. Effect of some plant products and other materials on development of pulse beetle, Callosobruchus chinensis (L.) on stored pigeonpea, Cajanus cajan (L.) Millsp. Journal of Insect Science 10:196-197.

Steidle, J.L.M., D. Rees and E.J. Wright. 2001. Assessment of Australian Trichogramma species (Hymenoptera: Trichogrammatidae) as control agents of stored product moths. Journal of Stored Products Research 37:263-275.

Tadesse, A. and T. Basedow. 2004. A survey of insect pest problems and stored product protection in stored maize in Ethiopia in the year 2000. Zeitschrift für Pflanzenkrankheiten und Pflanzenschutz, 111:257265.

Talukder, F.A. 1995. Isolation and characterization of the active secondary Pithraj (Aphanamixis polystachya) compounds in controlling stored-product insectpests. PhD thesis. University of Southampton, United Kingdom.

Talukder, F.A. and P.E. Howse. 1994. Laboratory evaluation of toxic and repellent properties of the pithraj tree, Aphanamixis polystachya Wall \& Parker, against Sitophilus oryza (L.). International Journal of Pest Management 40:274-279.

Talukder, F.A. and P.E. Howse. 1995. Evaluation of Aphanamixis polystachya as repellents, antifeedants, toxicants and protectants in storage against Tribolium castaneum (Herbst). Journal of Stored Products Research 31:55-61.

Talukder, F.A. and T. Miyata. 2002. In vivo and in vitro toxicities of pithraj and neem against rice green leafhopper (Nephotettix cincticeps Uhler). Zeitschrift für Pflanzenkrankheiten und Pflanzenschutz 109:543550.

Talukder, F.A., M.S. Islam, M.S. Hossain, M.A. Rahman and M.N. Alam. 2004. Toxicity effects of botanicals and synthetic insecticides on Tribolium castaneum (Herbst) and Rhyzopertha dominica (Fabricius).
Bangladesh Journal of Environmental Sciences 10: 365-371.

Tripathi, A.K., V. Prajapati, K.K. Aggarwal, S.P.S. Khanuja and S. Kumar. 2000. Repellency and toxicity of oil from Artemisia annua to certain stored-product beetles. Journal of Economic Entomology 93:43-47.

Tunc, I., B.M. Berger, F. Erler and F. Dagli. 2000. Ovicidal activity of essential oils from five plants against two stored-product insects. Journal of Stored Products Research 36:161-168.

Wallbank, B.E. and H.G. Greening. 1976. Insecticide resistance in grain insects. Agriculture Gazette of New South Wales 87:29-31.

White, N.D.G. and F.L. Watters. 1984. Incidence of malathion resistance in Tribolium castaneum and Cryptolestes ferrugineus populations collected in Canada. Proceedings of the 3rd International Working Conference for Stored-Product Entomology. October 23-28, 1983, Kansas, U.S.A. pp. 290-302.

White, N.D, P.K. Harein and R.N. Sinha. 1985. Current status of insecticide recommendations for managing stored grain in Canada and the United States. Minnesota Agricultural Experiment Station Bulletin. AD-SB-2565.

Xie, Y.S., P.G. Field and M.B. Isman. 1995. Repellency and toxicity of azadirachtin and neem concentrates to three stored-product beetles. Journal of Economic Entomology 88:1024-1031.

Yao, M.C. and K.C. Lo. 1995. Phoxim resistance in Sitotroga Cerealella Olivier in Taiwan. Journal of Agricultural Research of China 44:166-173.

Zettler, J.L. 1991. Pesticide resistance in Tribolium castaneum and Tribolium confusum (Coleoptera: Tenebrionidae) from flour mills in the USA. Journal of Economic Entomology 84:763-767.

Zettler, J.L. and G.W. Cuperus. 1990. Pesticide resistance in Tribolium castaneum (Coleoptera: Tenebrionidae) and Rhyzopertha dominica (Coleoptera: Bostrichidae) in wheat. Journal of Economic Entomology 83:16771681 .

Zettler, L.J. and D.W. Keever. 1994. Phosphine resistance in cigarette beetle (Coleoptera: Anobiidae) associated with tobacco storage in the Southeastern United States. Journal of Economic Entomology 87:546-550.

Received: June 2005

Accepted: November 2007 